\title{
AIR-ASSISTANCE AND LOW VOLUME APPLICATION TO CONTROL OF ASIAN RUST ON SOYBEAN CROP
}

\author{
Rafael de Souza Christovam*, Carlos Gilberto Raetano, Evandro Pereira Prado, \\ Mário Henrique Ferreira do Amaral Dal Pogetto, Hélio Oliveira Aguiar Júnior, \\ Marcelo Júnior Gimenes, Marina Elisei Serra
}

São Paulo State University "Julio de Mesquita Filho", Vegetal Production Department, P.O Box 237, Postal Code 18610-307, Botucatu, São Paulo, Brazil

Received: May 8, 2009

Accepted: August 2, 2010

\begin{abstract}
Currently, one of factors that cause the production cost increase of soybean crop is the pesticide application. The most important disease in soybean crop is Asian rust, caused by Phakopsora pachyrhizi Sydon \& P. Sydon fungus, which can cause significant loss of the production. Therefore, this work aimed at evaluation of different spraying techniques on the spray deposits and some parameters of soybean crop: grain size, weight of 1000 seeds and the crop productivity. Two experiments were carried out in the experimental area of FCA/UNESP (Faculdade de Ciencias Agronomicas/Universidade Estadual Paulista "Julio de Mesquita Filho") - Botucatu, SP, Brazil, in soybean crop, Conquista variety, in the 2007/2008 season. In the first experiment, three air levels (0, 9 and 29 $\mathrm{km} / \mathrm{h}$ of the air speed generated by fan) with flat fan nozzle XR 8002 with a spray volume of 130 1/ha were compared with a rotating nozzle - using low volume oily - LVO at $40 \mathrm{l} / \mathrm{ha}$ of spray volume. The second experiment was carried out under the same conditions as the previous experiment, including a control treatment (untreated plants). The disease severity was evaluated using a diagrammatic scale with a visual evaluation of the disease on 15 leaves of each plot. The grades varied between 0.6 and $78.5 \%$ of the disease severity. The use of air assistance when compared with the rotating system nozzle did not show significant differences for spray deposits on adaxial and abaxial surface of the leaves in bottom part of the plant. The air assistance with maximum air speed $(29 \mathrm{~km} / \mathrm{h})$ increased the productivity with respect of the other treatments.
\end{abstract}

Key words: spray technology, low volume oily, pest control, productivity

\section{INTRODUCTION}

Nowadays, soybean rust deserved special attention due its severity and difficulty of control, since it develops on the aerial part of plants, damaging physiology and contributing to a drastic reduction of productivity. Soybean Asian rust disease when not controlled can cause total loss of the production (Yorinori 2004).

In Brazil, crops free of disease can have an average productivity of $3300 \mathrm{~kg} / \mathrm{ha}$. However, with the production cost included for a return, not profitis $2436 \mathrm{~kg} / \mathrm{ha}$, thus it is recommendable to control causal agent of the disease (Yorinori 2005).

One of the techniques used to improve pesticide efficiency against $P$. pachyrhizi is a correct application of droplet size that provides good coverage, varying between 200 and 300 micrometers (Ozkan 2005). However, droplet smaller than $100 \mu \mathrm{m}$ can be used with drift control in spraying, with air assistance near to the sleeve boom.

For products with lesser systemic action, the use of smaller droplets and/or greater spray volume becomes necessary, due to greater dependence with respect to the target coverage. Systemic products can be applied with lower density of droplets allowing the use of larger droplets, which facilitates the adoption of techniques for drift reduction and improves security, increasing the efficiency rate. Large droplets provide a good level of deposit if used correctly, but it does not provide good conditions to spray coverage and canopy penetration (Antuniassi 2006).

Recently, the use of centrifugal energy to produce spray droplets (rotating system nozzle) is an interesting alternative of application technology to control of soybean Asian rust, using oily formulations, low spraying volumes and, consequently, a greater operational performance of sprayers.

In Brazil, new techniques for pesticide application using low volumes and rotating nozzles were developed in the West Region (Cerrado) for soybean rust control in soybean crop. Thus, the present work aimed at the comparison of the rotating nozzle - low volume oily LVO and different levels of air speed with an air-assisted sprayer on spray deposits, soybean Asian rust control and soybean productivity. 


\section{MATERIALS AND METHODS}

The experiments were carried out in the Experimental Farm of Agricultural Sciences Faculty of Sao Paulo State University - FCA/UNESP - Botucatu, São Paulo, Brazil, on soybean plants, Conquista variety, in the 2007/2008 season. The area is located at 724 meters above sea-level, with the following geographic coordinates: $22^{\circ} 48^{\prime} 59.7^{\prime \prime}$ $\mathrm{S}$ and $48^{\circ} 25^{\prime} 38.2^{\prime \prime} \mathrm{W}$, with wind predominant direction East - West.

The soybean sowing was performed in 23/11/2007, with crop row spaced at $0.45 \mathrm{~m}$ and no-tillage system. The crop was harvested in 29/04/2008.

The experimental design was in random blocks, with 4 treatments, three of them with different levels of airassistance in the sleeve boom: 0 (conventional spraying), 9 and $29 \mathrm{~km} / \mathrm{h}$ (maximum speed) generated by a fan and rotating system, using low oily volume, in five replications, total of 20 experimental plots, as shown in table 1.

Table 1. Different spraying technologies in the soybean crop

\begin{tabular}{|c|l|c|}
\hline Trat. & \multicolumn{1}{|c|}{ Equipment for spraying } & $\begin{array}{c}\text { Air speed } \\
{[\mathrm{km} / \mathrm{h}]}\end{array}$ \\
\hline 1. & Spraying without air (conventional) & 0 \\
\hline 2. & Spraying with air assistance & 9 \\
\hline 3. & Spraying with air assistance & $29^{*}$ \\
\hline 4. & Spraying with rotating nozzles (LVO) & 0 \\
\hline
\end{tabular}

*fan operated at maximum speed in the Advance Vortex 2000 sprayer

LVO - low volume oily

A cupric tracer was used to quantify the spray deposits. The cupric tracer concentration used in the experiment was approximately nine times lower $(0.32 \mathrm{~kg} / \mathrm{ha})$ when compared with copper oxichloride dosage recommended to a number of sensitive crops in Brazil, around $2.5 \mathrm{~kg} / \mathrm{ha}$ (Andrei 2005). The cupric tracer was applied in the same date as the first fungicide spraying. During the tracer spraying, the characteristics were the following:

- for the Advance Vortex 2000 sprayer without air assistance in the sleeve boom (conventional) and with 9 and $29 \mathrm{~km} / \mathrm{h}$ of the air speed generated by the fan relative air humidity of $57.8 \%$, temperature $28^{\circ} \mathrm{C}$ and wind speed of $3.8 \mathrm{~km} / \mathrm{h}$, in the period between $10: 05 \mathrm{~h}$ am and $11: 15 \mathrm{~h} \mathrm{am}$,

- for the Condor AM 12 Sprayer (equipped with rotating system - LVO) - relative air humidity of $56.2 \%$, temperature $29^{\circ} \mathrm{C}$ and wind speed of $5.6 \mathrm{~km} / \mathrm{h}$, in the period between $11: 40 \mathrm{~h}$ am and $12: 00 \mathrm{~h} \mathrm{pm}$.

One spraying was performed in the $\mathrm{R} 2$ growth stage, 98 days after sowing (DAS), using a tracer with concentration of $0.25 \mathrm{~kg}$ copper oxichloride (50\% metallic copper) per 100 liters of water, and an Advance Vortex 2000 sprayer with sleeve boom of $18.5 \mathrm{~m}$ of length, equipped with 37 flat fan nozzles XR 8002, spaced at $0.50 \mathrm{~m}$ and with $0.50 \mathrm{~m}$ distance from the target, at $287 \mathrm{kPa}$ working pressure and spray volume of $130 \mathrm{l} / \mathrm{h}$. The sprayer speed was $7.2 \mathrm{~km} / \mathrm{h}$.
For the spraying with rotating nozzles (LVO), a Condor AM-12 sprayer (automatic) was used, with $13 \mathrm{~m}$ of sleeve boom length, equipped with 9 rotating nozzles spaced of $1.35 \mathrm{~m}$ between them. The restrictor outflow nozzle used was the D2 with diffuser (core) 13, operating at 621 $\mathrm{kPa}$ of working pressure and spray volume of $40 \mathrm{l} / \mathrm{ha}$. The average rotation to calibration of the system was $5,941 \mathrm{rpm}$ and the sprayer speed was $5.3 \mathrm{~km} / \mathrm{h}$.

The experimental plots were $8.0 \times 10.0 \mathrm{~m}$ (width $\mathrm{x}$ length). From each plot, samples of ten plants were selected at random to quantify the spraying deposits.

Preparation for spraying with rotating system this was prepared separately using a 20 liter bucket (for tracer and fungicide), in the following order: first the mineral oil was added (Nimbus $0.5 \%$ of the volume), later the tracer ( $0.25 \mathrm{~kg}$ of copper oxychloride per 100 liters of water) and/or the azoxystrobin + ciproconazole fungicidal mixture (Priori xtra $0.30 \mathrm{l}$ p.c./ha) and after that the mixture of two products was used for homogenization. The vegetable oil (soy oil $0.76 \mathrm{l} / \mathrm{ha}$ ) was added to the adhesive spreader (Agral 0.04 1/ha) and at the end, 10 liters of water were added containing the agitation while supplying in the spray tank.

Preparation for spraying with Advance Vortex 2000 this was realized separately in a 20 liter bucket (for tracer as well as for fungicide) and the order of mixture was: first the mineral oil was added (Nimbus to $0.5 \%$ of the volume), later the tracer $(0.25 \mathrm{~kg}$ of copper oxichloride per 100 liters of water) and/or the azoxystrobin + ciproconazole fungicidal mixture (Priori xtra 0,3 1 p.c./ha), and at the end, 10 liters of water was added, the constant agitation and then, put into the spray tank.

Artificial targets (paper-filter with dimensions of $0.03 \times 0.03 \mathrm{~m}$ ) were distributed among 10 plants in the plots in perpendicular direction of the displacement of the sprayer. In each one of the 10 plants, four collectors were attached, one in the adaxial surface and another one in the abaxial surface of the same leaf, in the top and bottom parts of the plant.

For spraying loss evaluation, three Petri dishes of $0.085 \mathrm{~m}$ of diameter were used (with a paper-filter in each one). They were placed in each treatment at $0.10 \mathrm{~m}$ height above the ground in the field road, inside and outside of the crop canopy.

After spraying, the artificial targets were removed and put in glass jars containing 0.021 of nitric acid solution at $1.0 \mathrm{~mol} / \mathrm{l}$ and, after fifteen minutes of stirring at $220 \mathrm{rpm}$, there followed 24 hours without agitation. Subsequently, the washed solutions were taken to a spectrophotometer with atomic absorption, model AA-6300 SHIMADZU for the quantification of the copper ion $(\mathrm{Cu})$, according to the methodology used by Chaim et al. (1999). The Petri dishes distributed inside and outside of the canopy were also washed with the same amount of the extracted solution and the same procedure was applied for the quantification of the tracer.

The data for the tracer was analyzed from the abaxial and adaxial surfaces of the leaves separately in different parts of the plant (top and bottom). The data was submitted to a variance analysis and the averages compared by Tukey's test $(\mathrm{p}<0.05)$. 
The second experiment was carried out in the same place and the treatments distributed in the same design as that of the previous experiment, using one control treatment (untreated plants). This experiment constituted of five treatments and five replications, totalizing 25 experimental plots.

During the first spraying of the azoxystrobin + ciproconazole fungicidal mixture, at 98 DAS, in R2 growth stage, the climatic conditions, for the respective techniques, were:

- Advance Vortex 2000 sprayer using air-assistance (0.9 and $29 \mathrm{~km} / \mathrm{h}$ of the air speed) - relative air humidity of $60.7 \%$, wind speed between 5.3 and $9.5 \mathrm{~km} / \mathrm{h}$ and temperature of $27.9^{\circ} \mathrm{C}$ in the period between 3:00-3:30 $\mathrm{h}$ $\mathrm{pm}$,

- Condor AM 12 sprayer (equipped with rotating system - LVO) - relative air humidity of $59.1 \%$, wind speed between 3.0 and $6.5 \mathrm{~km} / \mathrm{h}$ and temperature of $27.5^{\circ} \mathrm{C}$ in the period between $4: 00$ and $4: 30 \mathrm{~h} \mathrm{pm}$.

In the second spraying of the fungicidal mixture, at 113 DAS, in the R5.2 growth stage of the culture, climatic conditions for the respective techniques were:

- Advance Vortex 2000 sprayer using air-assistance ( 0.50 and $100 \%$ of the maximum air speed generated by fan) - relative air humidity of $60.7 \%$, wind speed between 5.3 and $10.3 \mathrm{~km} / \mathrm{h}$ and temperature of $27.4^{\circ} \mathrm{C}$ in the period between 3:00 and 4:00 h pm,

- Condor AM 12 sprayer (equipped with rotating system - LVO) - relative air humidity of $79.8 \%$, wind speed between 6.5 to $11.0 \mathrm{~km} / \mathrm{h}$ and temperature of $20.5^{\circ} \mathrm{C}$ in the period between 7:00 and 7:30 $\mathrm{h} \mathrm{pm}$.

In R2 and R5.2 growth stages, a spraying with the azoxystrobin + ciproconazole fungicidal mixture was done, respectively at 98 and 113 days after sowing (DAS). The calibration was the same as the ones used in the previous experiment. Before and after each spraying, evaluations of the disease severity were performed weekly, using a diagrammatic scale of Godoy et al. (2006) expressed by percentage of disease on leaves. The leaves were removed from the bottom part of the plant.

The following crop parameters were evaluated: weight of 1000 seeds and their classification by bolters mesh. Also was evaluated the crop productivity ( $\mathrm{kg} / \mathrm{ha})$.
The data was submitted to the variance analysis and the averages compared by Tukey's test at $5 \%$ of significance level.

\section{RESULTS AND DISCUSSION}

\section{Spray deposit on the leaves}

The values of spray deposits, expressed in volume on artificial targets in different positions of the soybean plant, are shown in table 2.

In general, it could be verified that the air-assistance promoted the increase as compared to conventional spraying (without air) and rotation system - LVO deposit levels in the adaxial surface of the leaf located in the top part of the plants. Therefore, in the bottom part, there was not a significant difference in the spray deposits between the spraying techniques. Also, the abaxial surface did not show difference of deposit levels, in the top/bottom part, between the spraying techniques.

For the different techniques, only air-assistance promoted differences of deposit levels between the top/bottom part of the plant, in the abaxial and adaxial surface of the leaves (Table 2).

Monteiro (2006) performed a research that aimed to evaluate the spraying efficiency of a rotating atomizer system LVO using 25 1/ha of fungicide outflow in the soybean crop, when compared to a sprayer equipped with hydraulic nozzles at 150 1/ha of spray volume. The author observed results very similar with these obtained in this research. In another experiment also performed by Monteiro (2006), with the aim to verify the efficiency of tebuconazole applied with hydraulical nozzles (120 1/ha) compared to applications in low volume oily, using soybean oil (20 and 30 1/ha of spray volume), obtained similar results to control of Asian rust on soybean crop in Brazil.

\section{Evaluation of the spraying losses}

The spray losses inside and outside of the canopy and in the field road using different technologies are shown in table 3 . There were not significant differences in the spray volumes captured inside and outside of the canopy $(1.0 \mathrm{~m}$ of the end of the sleeve boom) using different air speeds near the spray boom or when the spraying was realized with low volume oily.

Table 2. Average of the cupric tracer deposits sprayed with different techniques at artificial target (paper-filter) on leaves surfaces, in the top/bottom part of the soybean plants, Conquista variety. Botucatu, SP, Brazil, 2007/2008

\begin{tabular}{|c|c|c|c|c|}
\hline \multirow{3}{*}{ Equipment } & \multicolumn{2}{|c|}{ Adaxial } & \multicolumn{2}{|c|}{ Abaxial } \\
\hline & top & bottom & top & bottom \\
\hline & \multicolumn{2}{|c|}{$\left[\mu \mathrm{l} / \mathrm{cm}^{2}\right]$} & \multicolumn{2}{|c|}{$\left[\mu \mathrm{l} / \mathrm{cm}^{2}\right]$} \\
\hline 0 & $1.0041 \mathrm{aB}$ & $0.8794 \mathrm{aA}$ & $0.8532 \mathrm{aA}$ & $0.8481 \mathrm{aA}$ \\
\hline 9 & $1.2316 \mathrm{aA}$ & $0.9456 \mathrm{bA}$ & $0.8852 \mathrm{aA}$ & $0.8832 \mathrm{aA}$ \\
\hline 29 & $1.1655 \mathrm{aAB}$ & $0.8630 \mathrm{bA}$ & $0.9410 \mathrm{aA}$ & $0.8224 \mathrm{bA}$ \\
\hline LVO & $0.9552 \mathrm{aB}$ & $0.9026 \mathrm{aA}$ & $0.8605 \mathrm{aA}$ & $0.8382 \mathrm{aA}$ \\
\hline DMS (equipment) & \multicolumn{2}{|c|}{0.20} & \multicolumn{2}{|c|}{0.10} \\
\hline DMS (plant position) & \multicolumn{2}{|c|}{0.15} & \multicolumn{2}{|c|}{0.08} \\
\hline CV [\%] & \multicolumn{2}{|c|}{11.43} & \multicolumn{2}{|c|}{6.80} \\
\hline
\end{tabular}

Averages followed by the same letter, smaller on the line and bigger in the column, did not differ by Tukey's test at $5 \%$ significance level; DMS - different minimum significant 
Higher volumes could be detected in targets located in the field road, because there were not barrier between the targets in this place.

Lower deposits were obtained inside and outside of the canopy by interception of the spray droplets by the leaves, independent of the application technique (Table 3).

\section{Severity of the Asian rust}

The average results of the foliar injury percentage, before and after two sprayings (R2 and R5.2 growth stages) with azoxystrobin + ciproconazole fungicidal mixture to control of P. pachyrhizi, are shown in table 4, by Area Under Disease Progress Curve (AUDPC). After spraying with the fungicide mixture, significant reduction of injuries in the foliar area could be verified.

A significant difference was not observed between the conventional treatments (without air), 9 and $29 \mathrm{~km} / \mathrm{h}$ of air speed generated by fan and LVO after two sprayings of the fungicidal mixture. The rotating nozzle technique - LVO showed a significant difference when compared with other treatments, only after the second spraying with the fungicidal mixture, at 133 DAS (Table 4).

The evolution of Asian rust disease in soybean plants, Conquista variety, shown as the percentage of injury per area, before and after the spraying is presented in figure 1 .
In general, after the second spraying of the fungicidal mixture, the percentage of injury per area increased until 120 DAS. This occurrence can be related with the high severity of disease (more that $5 \%$ ) in the control period.

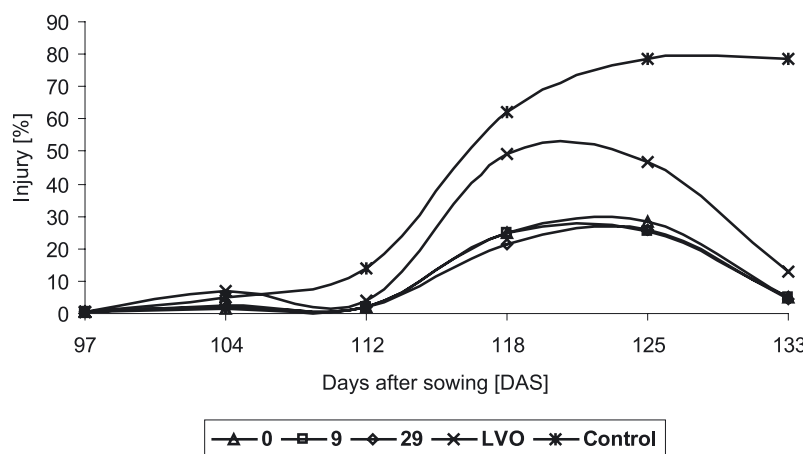

Fig. 1. Severity of the soybean Asian rust before and after two sprayings (R2 and R5.2), respectively at 98 and 113 DAS, with azoxystrobin + ciproconazole fungicidal mixture to control of P. pachyrhizi. Botucatu SP, Brazil, 2007/2008

Table 3. Average spray volume in Petri dishes $\left[\mu \mathrm{l} / \mathrm{cm}^{2}\right]$ located in different positions of canopy and equipment (air speed and LVO), in soybean crop, Conquista variety. Botucatu, SP, Brazil, 2007/2008

\begin{tabular}{|c|c|c|c|c|c|c|c|c|}
\hline \multirow{3}{*}{$\begin{array}{l}\text { Collector position } \\
\text { Outside }\end{array}$} & \multicolumn{8}{|c|}{ Equipment } \\
\hline & \multicolumn{2}{|c|}{0} & \multicolumn{2}{|c|}{$9 \mathrm{~km} / \mathrm{h}$} & \multicolumn{2}{|c|}{$29 \mathrm{~km} / \mathrm{h}$} & \multicolumn{2}{|c|}{ LVO } \\
\hline & 0.7141 & $\mathrm{aA}$ & 0.7204 & $\mathrm{aB}$ & 0.7194 & $\mathrm{aB}$ & 0.7660 & $\mathrm{aB}$ \\
\hline Inside & 0.7173 & $\mathrm{aA}$ & 0.7523 & $\mathrm{aB}$ & 0.7384 & $\mathrm{aB}$ & 0.7235 & $\mathrm{aB}$ \\
\hline Field road & 0.7389 & $\mathrm{cA}$ & 0.8872 & $\mathrm{abA}$ & 0.9497 & $\mathrm{aA}$ & 0.8440 & $\mathrm{bA}$ \\
\hline CV [\%] & \multicolumn{8}{|c|}{7.18} \\
\hline DMS (collector position) & \multicolumn{8}{|c|}{0.08} \\
\hline DMS (equipment) & \multicolumn{8}{|c|}{0.09} \\
\hline
\end{tabular}

Averages followed by the same letter, smaller in the line and bigger in the column, did not differ by Tukey's test at $5 \%$ significance level

Table 4. Percentage of injury represented by Area Under Disease Progress Curve (AUDPC), in soybean plants, after two spraying with the azoxystrobin + ciproconazole fungicidal mixture at 98 and 113 DAS on (R2 and R5.2 growth stages) to control of P. pachyrhizi. Botucatu, SP, Brazil, 2007/2008

\begin{tabular}{|c|c|c|c|c|c|c|}
\hline \multirow{2}{*}{ Equipment } & \multicolumn{7}{|c|}{ Days after sowing (DAS) } \\
\cline { 2 - 7 } & 104 & 112 & 118 & 125 & 133 & Total \\
\hline Without air -0 & $1.48 \mathrm{a}$ & $1.94 \mathrm{~b}$ & $24.77 \mathrm{~b}$ & $28.37 \mathrm{~b}$ & $5.05 \mathrm{c}$ & $62.21 \mathrm{c}$ \\
\hline With air -9 & $2.49 \mathrm{a}$ & $2.17 \mathrm{~b}$ & $24.92 \mathrm{~b}$ & $25.55 \mathrm{~b}$ & $4.93 \mathrm{c}$ & $60.69 \mathrm{c}$ \\
\hline With air - 29 & $1.78 \mathrm{a}$ & $2.14 \mathrm{~b}$ & $21.61 \mathrm{~b}$ & $26.05 \mathrm{~b}$ & $4.50 \mathrm{c}$ & $56.68 \mathrm{c}$ \\
\hline LVO & $7.03 \mathrm{a}$ & $3.95 \mathrm{~b}$ & $49.29 \mathrm{ab}$ & $46.58 \mathrm{~b}$ & $13.15 \mathrm{~b}$ & $120.59 \mathrm{~b}$ \\
\hline Control & $5.19 \mathrm{a}$ & $13.86 \mathrm{a}$ & $61.94 \mathrm{a}$ & $78.50 \mathrm{a}$ & $78.50 \mathrm{a}$ & $238.65 \mathrm{a}$ \\
\hline CV [\%] & 110.54 & 70.45 & 44.79 & 30.78 & 17.06 & 27.08 \\
\hline DMS & 7.52 & 6.42 & 30.96 & 23.89 & 6.86 & 55.24 \\
\hline
\end{tabular}

Averages followed by the same letter, in the column, did not differ by Tukey's test at $5 \%$ significance level 
Table 5. Average percentage of the soybean grain size, classified by bolters, after two spraying (R2 and R5.2) of the azoxystrobin + ciproconazole fungicidal mixture, with different spray techniques to control of P. pachyrhizi. Botucatu, SP, Brazil, 2007/2008

\begin{tabular}{|c|c|c|c|c|c|c|}
\hline \multirow{2}{*}{ Equipment } & \multicolumn{7}{|c|}{ Bolters } \\
\cline { 2 - 7 } & 18 & 17 & 16 & 15 & 14 & deep \\
\hline Without air -0 & $31.88 \mathrm{a}$ & $35.41 \mathrm{a}$ & $21.49 \mathrm{~b}$ & $7.09 \mathrm{~b}$ & $2.28 \mathrm{~b}$ & $1.87 \mathrm{~b}$ \\
\hline With air -9 & $25.14 \mathrm{a}$ & $34.99 \mathrm{a}$ & $25.12 \mathrm{ab}$ & $9.84 \mathrm{~b}$ & $2.85 \mathrm{~b}$ & $2.08 \mathrm{~b}$ \\
\hline With air - 29 & $26.24 \mathrm{a}$ & $36.32 \mathrm{a}$ & $24.64 \mathrm{ab}$ & $8.53 \mathrm{~b}$ & $2.50 \mathrm{~b}$ & $1.77 \mathrm{~b}$ \\
\hline LVO & $22.27 \mathrm{a}$ & $34.51 \mathrm{a}$ & $27.42 \mathrm{ab}$ & $10.49 \mathrm{~b}$ & $3.02 \mathrm{~b}$ & $2.33 \mathrm{~b}$ \\
\hline Control & $7.96 \mathrm{~b}$ & $20.11 \mathrm{~b}$ & $32.76 \mathrm{a}$ & $24.53 \mathrm{a}$ & $9.63 \mathrm{a}$ & $5.01 \mathrm{a}$ \\
\hline DMS & 14.14 & 4.36 & 8.37 & 4.80 & 1.87 & 0.57 \\
\hline CV [\%] & 32.91 & 7.13 & 16.83 & 20.97 & 24.32 & 11.63 \\
\hline
\end{tabular}

Averages followed by the same letter, in the column, did not differ by Tukey's test at $5 \%$ significance level

\section{Evaluation of the yield parameters and productivity}

In relation to the average percentage of the grain size, classified by bolters, it can be conducted that the techniques used for spraying of the azoxystrobin + ciproconazole fungicidal mixture, significantly contributed to the production of larger grains, in relation to those plots not treated (control).

The average percentage of smaller grains in relation to the restrained ones in bolter 14 that comprise the deep one in the control treatment was significantly higher in comparison with other treatments (Table 5).

Comparing the spraying techniques used for control of the Asian rust it can be verified that the highest percentage of restrained grains was in bolter 17. The treatment using the maximum air speed generated by a fan $(29 \mathrm{~km} / \mathrm{h})$ provided a greater percentage of restrained grains in bolter 17, but it was not sufficient to show a significant difference between plots sprayed with fungicide (Table 5)

Table 6. Average weight of 1000 seeds and productivity of the soybean crop after two sprayings (R2 and R5.2) with the azoxystrobin + ciproconazole fungicidal mixture in different spraying techniques to control of $P$. pachyrhizi. Botucatu, SP, Brazil, 2007/2008

\begin{tabular}{|c|c|c|}
\hline Equipment & $\begin{array}{c}\text { Weight of } 1000 \\
\text { seeds [g] }\end{array}$ & $\begin{array}{c}\text { Productivity }[\mathrm{kg} / \\
\text { ha] }\end{array}$ \\
\hline Without air $-0 \mathrm{~km} / \mathrm{h}$ & $181.31 \mathrm{a}$ & $2852.79 \mathrm{a}$ \\
\hline With air $-9 \mathrm{~km} / \mathrm{h}$ & $181.92 \mathrm{a}$ & $2717.92 \mathrm{a}$ \\
\hline With air $-29 \mathrm{~km} / \mathrm{h}$ & $175.88 \mathrm{a}$ & $3062.58 \mathrm{a}$ \\
\hline Rotating nozzle - LVO & $168.27 \mathrm{a}$ & $2747.89 \mathrm{a}$ \\
\hline Control & $141.01 \mathrm{~b}$ & $1457.30 \mathrm{~b}$ \\
\hline DMS & 21.00 & 662.32 \\
\hline CV [\%] & 6.57 & 13.63 \\
\hline
\end{tabular}

Averages followed by the same letter, in the column, did not differ by Tukey's test at $5 \%$ significance level

The average weight of 1000 seeds and productivity (kg/ha) after two sprayings (R2 and R5.2 growth stages) with azoxystrobin + ciproconazole fungicidal mixture using different techniques, is shown in table 6 . The treatments sprayed with the fungicidal mixture provide a weight of 1000 seeds and productivity significantly higher in comparison with not treated plants (control). The highest increase of productivity was obtained with the maximum air speed generated by the fan $(29 \mathrm{~km} / \mathrm{h})$ near to spray boom using 130 1/ha when compared with the control treatment. The spray volume applied with the rotating system nozzle - LVO was $401 /$ ha). Therefore it did not provide the same increase in productivity compared with the treatment using air-assistance in the maximum speed. The rotating system nozzle was $30 \%$ more economic than the treatment with spray volume of $130 \mathrm{l} / \mathrm{ha}$, with or without air--assistance near the boom, using the Advance Vortex 2000 sprayer.

\section{CONCLUSIONS}

Based on the experimental conditions where the study was performed and from the results obtained, it is possible to conclude that the rotating system nozzle at low volume oily - LVO provided lower levels of control of the Asian rust disease when compared to spray techniques using air-assistance, but the soybean crop productivity was similar with a third part of applied volume by rotating nozzle - LVO (40 1/ha). Different technologies not influenced on spray deposits in bottom part of the plants, essential to initial control of the disease. The air-assistance contributed to the increase of spray deposit levels in the top of soybean plants. The rotating system nozzles in the control of soybean Asian rust can be influenced by their rotation speed and spray volume.

\section{REFERENCES}

Andrei E. 2005. Compêndio de Defensivos Agrícolas. 7th ed. Andrei Editora Ltda, São Paulo, 1141 pp.

Antuniassi U.R. 2006. Tecnologia de aplicação de defensivos na cultura da soja. 193-219. In: "Boletim Técnico de Pesquisa Soja 2006" (S. Suzuki, M.M. Yuyama, S.A. Camacho, eds.). Fundação Mato Grosso, Rondonópolis.

Chaim A., Valarini P.J., Oliveira D.A., Morsoleto R.V., Pio L.C. 1999. Avaliação de Perdas de Pulverização em Cultura de Feijão e Tomate. Embrapa Meio Ambiente, Jaguariúna, (Boletim de Pesquisa). 29 pp.

Godoy C.V., Hoga L.J., Canteri M.G. 2006. Diagrammatic scale for assessment of soybean rust severity. Fitopatologia Brasileira 31 (1): 63-68.

Monteiro M.V.M. 2006. BVO Terrestre. Manual de Operação Para Aplicações Terrestres em BVO. Centro Brasileiro de Bioaeronautica, Sorocaba, 9 pp. 
Ozkan E. 2005. Best spraying strategies to fight against Soybean Rust. Disposable in: http://www.jacto.com/soybean_rust. html.

Yorinori J.T., Júnior J.N., Lazzarotto J.J. 2004. Ferrugem “Asiática" da Soja no Brasil: Evolução, Importância Econômica e Controle. EMBRAPA soja, Londrina. (Documentos, 247), $36 \mathrm{pp}$.

Yorinori J.T. 2005. A ferrugem asiática da soja no continente americano: evolução, importância econômica e estratégias de controle. p. 21-37. In: Workshop Brasileiro sobre a Ferrugem Asiática. Agosto 2005, Uberlândia, Coletânea, EDUFU, Uberlândia.

\section{POLISH SUMMARY}

\section{STOSOWANIE POWIETRZA I OBNIŻONYCH OBJĘTOŚCI CIECZY W ZWALCZANIU RDZY AZJATYCKIEJ SOI}

Obecnie, jednym z czynników powodujących wzrost kosztów produkcji soi jest stosowanie środków ochrony roślin. Najważniejszą chorobą soi jest azjatycka rdza soi wywoływana przez grzyb Pakospora pachyrhizi Sydon et P. Sydon, mogący spowodować duże straty w produkcji. W pracy porównywano różne techniki opryskiwania na depozyt preparatu opryskowego i niektóre parametry uprawy, jak: wielkość ziaren, waga 1000 nasion, produktywność roślin. Wykonano dwa doświadczenia na polu doświadczalnym FCA/UPESP - Botucatu, SP, Brazylia, w uprawie soi, odmiana Conquista, w sezonie 2007/2008. W pierwszym doświadczeniu wykorzystano różne poziomy szybkości powietrza (0,9 i $29 \mathrm{~km} / \mathrm{h})$ uzyskane przy pomocy wentylatora, posiadającego dyszę wachlarzową XR8002 o wydajności 130 1/ha. Porównywano ją z dyszą obrotowa, przystosowaną do niskiej objętości oleju 40 1/ha. Drugi eksperyment wykonano w tych samych warunkach, włączając kontrolę (rośliny nieopryskiwane). Nasilenie choroby oceniano na 15 liściach, na każdym poletku. Stopnie porażenia mieściły się $\mathrm{w}$ granicach 0,6 i $78,5 \%$. Wykorzystanie wariantu $\mathrm{z}$ powietrzem, w porównaniu z obrotowym systemem dysz, nie różniło się istotnie, gdy porównywano depozyty na obu stronach liści, na dolnej części roślin. Maksymalne wykorzystanie szybkości powietrza $(29 \mathrm{~km} / \mathrm{h})$, podnosiło efektywność $\mathrm{w}$ porównaniu $\mathrm{z}$ innymi technikami. 